\title{
Emissions Trading, Wealth Transfers and the Wounded-Bull Scenario in Power Generation
}

\author{
Paul Simshauser* \\ AGL Energy Ltd \\ Level 22, 101 Miller Street \\ North Sydney, NSW, 2060. \\ Thao Doan \\ Stanwell Corporation Limited \\ Level 12, Waterfront Place \\ 1 Eagle Street, Brisbane, QLD, 4000.
}

\begin{abstract}
Electricity generators accept that emissions trading is fundamental to meeting $\mathrm{CO}_{2}$ reduction targets. But unless a percentage of permits are allocated, existing generators will face non-trivial wealth transfers. Seldom contemplated in academic works are the adverse economic consequences of an all-auction approach to emissions trading. Using Victoria to illustrate, we find that once $\mathrm{CO}_{2}$ prices exceed \$17.50/t, the marginal coal generator facing large wealth transfers will withhold generating capacity to raise prices and recoup stranded investments, thus becoming a 'wounded-bull' in the market place. This has material welfare implications with modelling results indicate an intermediaterun 300 per cent increase in wholesale power prices.
\end{abstract}

\section{Introduction}

The environmental performance of the 41 000MW National Electricity Market (NEM), which incorporates Queensland, New South Wales, Victoria, South Australia and Tasmania, has deteriorated sharply following the microeconomic reforms of the mid-1990s. Faced with this dilemma, it became necessary for the State and Federal Governments to implement parallel environmental policies, all of which were aimed at improving the power industry's greenhouse footprint. But the schemes have tended to be piecemeal rather than comprising a single, national, broad-based Emissions Trading Scheme (ETS) aimed at curtailing $\mathrm{CO}_{2}$ emissions. After oscillating on the concept since 1999 (AGO, 1999), the Federal Government now seems committed to the implementation of an ETS in 2010.

The primary purpose of this article is to examine the likely consequences of a 'big bang' approach to this major microeconomic reform on the power generation industry, in particular, the consequences arising from an all-auction approach to permit issuance under an ETS, as opposed to a transitional path whereby some percentage of permits are freely allocated to generators in the first instance. Generators are non-trivial emitters of $\mathrm{CO}_{2}$, accounting for about 35 per cent of the nation's total. We examine wealth transfers without permit allocation and the intermediate-run instability in commodity prices that will almost certainly follow if wealth transfers are not dealt with in a structural adjustment policy through permit allocation. ${ }^{1}$ Using data from Victoria, simulation modelling has been carried out to quantify the cost impost on generators and to demonstrate the dominant strategy of rational profit-seeking generators when they are shifted from a position of strength as a high merit order base load plant, to being the region's weakest generator, that is, the marginal brown coal generator.

\footnotetext{
* Paul Simshauser is also Adjust Professor at the Griffith Business School. The views expressed in this paper are those of the authors and not necessarily those of Babcock \& Brown or Stanwell Corporation Limited.
} 
This paper is structured as follows. Section 2 reviews the arguments for and against the allocation of emissions permits, with reference to the lessons from the EU ETS phase I. Section 3 quantifies generator entry costs in Victoria. Section 4 calculates the price of $\mathrm{CO}_{2}$ that drives fuel switching in Victoria, which we refer to as the 'Tipping Point'. Section 5 presents an overview of the NEM market institutions along with modelling results of a Base Case Scenario and a TippingPoint Scenario for Victoria where $\mathrm{CO}_{2}$ pricing is implemented under an all-auction approach. This important scenario quantifies the economic losses and wealth transfers faced by coal-fired generators. Section 6 then presents the Wounded-Bull Scenario, the dominant strategy facing base load generators who become marginal participants following the pricing of $\mathrm{CO}_{2}$. Section 7 concludes.

\section{Emissions Trading and Permit Allocation Policy}

As natural emitters of $\mathrm{CO}_{2}$, the power generation industry in Australia favours an ETS over a carbon tax, and it would seem that most policy makers have formed the same view. The reason for this preference finds its roots in Coase (1960) and the theory of property rights. ${ }^{2}$ But a key determinant is how permit acquittal obligations are dealt with; whether adequate emission permits are allocated via a transition policy, or an all-auction approach is followed. To be sure, both methods will lead to an identical value for permits because they have an opportunity value (Linares et al. 2006). Critics of permit allocation have often cited the 'windfall profits' of generating portfolios in Europe to dismiss the importance of a proper implementation of a permit allocation policy. But as this paper later reveals, windfall profits need to be carefully assessed in terms of their true magnitude in Europe, and the likelihood (or lack thereof) in an Australian context.

It is the price of $\mathrm{CO}_{2}$ that will fundamentally change the operation of existing generators, future investments and emission levels - not the method in which permits are issued. As Sijm et al. (2005) have noted, whether allocated or auctioned, generators will attempt to pass on the full opportunity value of emission permits. But importantly, generators as a class are unlikely to achieve a 100 per cent pass-through rate because (a) different generating technologies have different emission rates (for example, brown coal 1.26t/MWh, black coal 0.9t/MWh, peaking gas plant $0.6 \mathrm{t} / \mathrm{MWh}$ and base load gas plant $0.4 \mathrm{t} / \mathrm{MWh}$ ), and (b) price determination in spot electricity markets incorporate a large number of constraints which can prevent 100 per cent pass-through:

...In principle, power producers will always [try to] pass on the full opportunity cost of freely allocated emission allowances in the sense that they will add these costs to their other marginal production costs. Producers, however, cannot simply set power prices as these are determined by a complex set of market forces. Hence, due to a variety of reasons, the [pass-through] rate may be significantly lower than [100 per cent]... In general, it is hard to assess the impact of $\mathrm{CO}_{2}$ allowance costs on power prices as these prices are determined by a large variety of factors including fuel prices, exchange rates, available production capacity, investment costs, imports, weather conditions, [must-run constraints such as] heat demand and, gas contract inflexibilities, expectations and sentiments of market players etc... Sijm et al. (2005, p.46, p.48)

As an energy-only market, the emphasis for producers in the NEM is on energy produced and the price received for such energy. Any increase in a power station's short run marginal cost to take account of the $\mathrm{CO}_{2}$ liability can cause a radical shift in a coal generator's position in the aggregate supply function, from a base load position (high-up in the power station merit order) to a marginal position (lower-down in the power station merit order). Such a change will lead to a reduction in emissions which is a desirable outcome, but it will also lead to a corresponding reduction in revenue and in profitability and thus the issue of permit allocation vs. an all-auction approach comes down to a wealth transfer issue. The power generation industry expects that policy makers will form a bias towards some level of permit allocation in order to facilitate 
structural adjustment (on economic grounds) and to ensure that the very disproportionate economic loss of value in relation to sunk assets are minimized (on equity grounds). The value at stake is substantial, with the sunk asset stock of the power generation industry in Australia representing an investment in excess of \$45 billion (Simshauser, Doan and Lacey 2007).

\subsection{Permit Allocation and the Importance of the Technology Mix}

The allocation of permits as a policy has been contentious. More specifically, the issue is the socalled 'windfall gains' reported to have been extracted by power generators in the European Union following the introduction of an ETS. This, it has been argued, was the result of an excess permit allocation based on historical generation patterns rather than allocated according to forecast economic loss. But the so-called 'windfall gains' does not make permit allocation a poor policy choice - it merely demonstrates the poor application of a policy. Additionally and most importantly, the so-called 'windfall gains' in the EU15 need to be analysed carefully in light of complex market dynamics and the plant technology mix - which differ radically from Australia. The portfolio technology mix by country, including Australia for comparative purposes, is listed in Table 1.

Table 1: $\quad$ Generation Mix and Average Carbon Intensity for the EU15 and Australia

\begin{tabular}{|c|c|c|c|c|c|c|}
\hline Country & $\begin{array}{r}\text { Generation } \\
\text { (TWh) }\end{array}$ & $\begin{array}{r}\text { Coal } \\
(\%) \\
\end{array}$ & $\begin{array}{r}\text { Oil } \\
(\%) \\
\end{array}$ & $\begin{array}{l}\text { Gas } \\
(\%) \\
\end{array}$ & $\begin{array}{r}\text { Non Fossil } \\
(\%)\end{array}$ & $\begin{array}{r}\text { Emissions } \\
\text { (t CO2/MWh) }\end{array}$ \\
\hline Germany & 567.1 & 52.7 & 0.8 & 9.3 & 37.2 & 0.468 \\
\hline France & 535.8 & 5.8 & 1.4 & 2.1 & 90.7 & 0.410 \\
\hline UK & 372.2 & 33.4 & 1.5 & 39.4 & 25.7 & 0.467 \\
\hline Italy & 269.9 & 11.3 & 31.8 & 37.5 & 19.4 & 0.506 \\
\hline Spain & 221.7 & 36.5 & 10.2 & 9.1 & 44.2 & 0.421 \\
\hline Australia & 201.1 & 84.3 & 0.3 & 7.7 & 7.6 & 0.915 \\
\hline Sweden & 145.9 & 2.1 & 1.2 & 0.3 & 96.4 & 0.016 \\
\hline Netherlands & 89.6 & 28.4 & 3.5 & 57.7 & 10.4 & 0.464 \\
\hline Belgium & 82.7 & 19.4 & 1.0 & 19.3 & 60.3 & 0.284 \\
\hline Finland & 70.0 & 18.9 & 0.9 & 14.4 & 65.8 & 0.253 \\
\hline Austria & 60.3 & 11.1 & 3.3 & 13.0 & 72.6 & 0.150 \\
\hline Greece & 53.4 & 64.2 & 16.6 & 11.1 & 8.1 & 0.807 \\
\hline Portugal & 43.4 & 33.9 & 19.4 & 16.5 & 30.2 & 0.468 \\
\hline Denmark & 36.2 & 46.0 & 12.2 & 24.3 & 17.5 & 0.373 \\
\hline Ireland & 23.7 & 36.3 & 19.6 & 39.1 & 5.0 & 0.670 \\
\hline Luxembourg & 0.4 & 0.0 & 0.0 & 53.1 & 46.9 & 0.108 \\
\hline EU15 Avg & $2,773.4$ & 28.6 & 8.8 & 23.1 & 39.5 & 0.353 \\
\hline Australia & 201.1 & 84.3 & 0.3 & 7.7 & 7.6 & 0.915 \\
\hline Difference & & 55.7 & -8.5 & -15.4 & -31.9 & 0.562 \\
\hline
\end{tabular}

There are a number of important differences between Australia and the EU15. The first and most important difference is the proportion of coal relative to other fuel sources. Australia at 84.3 per cent is substantially above the EU15 volume-weighted average of 28.6 per cent. Similarly, the EU15 sources 39.5 per cent of its power from non-fossil fuels. Australia's non-fossil power amounts to just 7.6 per cent. Finally, the average emissions intensity of the EU15 is, as a result, just 0.353t/MWh compared to Australia's 0.915t/MWh. Yet, the EU15 does have a number of coal fired plant in each region with emissions intensities that on average, resemble Australia's black coal fleet. Not surprisingly, when such plant set power prices, the remaining 71.4 per cent of plant with low or zero emission intensities can indeed be expected to make windfall gains. By comparison, in Australia only 7.6 per cent of plant output would be expected to extract supranormal profits whenever fossil-based generators are allowed to fully recover the $\mathrm{CO}_{2}$ cost. At the 
very least, this clearly indicates that Australia's transition path will be substantially more painful than the EU15, given the $\mathrm{CO}_{2}$ intensity of Australia's power station fleet.

A primary source of EU15 windfall gains was, as noted above, the use of historic data in determining permit allocations. Some plant included in the data set had already been, or were ear-marked, for closure which heightened gains. As Radov and Klevnas (2007) noted, in Germany, fossil-fired power station allocations totalled 382 million permits yet 2005 emissions were only 373 million tonnes of $\mathrm{CO}_{2}$. Clearly, the application of a policy designed to overallocate permits relative to current emission levels is questionable at best.

EU15 windfall gains are most unlikely to be replicated in Australia. There are three primary reasons for this. First, Australia will not over-allocate permits to existing generators or use historic production levels as the basis. Australian generators as a class might receive at best 30$50 \%$ of allocated permits (albeit with some generators receiving more and others less than the class average) as opposed to the 95\% across-the-board allocation in the EU15. This allocation lesson was painfully learned by the EU15. Second, about 85 per cent of Australia's power generation comes from coal sources, which are forecast to be adversely financially impacted by the entry of lower emitting gas-fired plant, and the overwhelming majority of Australian generators have little if any fuel diversification within their portfolios in terms of energy production to extract supra-normal profits. And third, the entire issue of permit allocation in Australia has, and will continue to be, the topic of intense scrutiny by the press, bureaucrats, policy advisors and politicians.

\subsection{The Pass-Through of $\mathrm{CO}_{2}$ Price}

Research by McKinsey (2005) indicated that firms in the EU15 generally incorporated the cost of emissions in approximately 70 per cent of marginal pricing decisions, thus implying a passthrough rate of 70 per cent. But in electricity markets, capturing the true pass-through rate is a non-trivial exercise because, as noted above, price formation in spot electricity markets are subject to many variables and constraints. For example, in the EU15, while at face value passthrough rates appeared to be close to 100 per cent, natural gas prices (and therefore gas-fired generation prices) rose very substantially in line with international oil prices at the same time $\mathrm{CO}_{2}$ prices were imposed on the market, and thus the true pass-through rate by generators as a class needs to be separated from underlying rises in unit fuel costs.

Radnov and Klevnas (2007) and Sijm et al. (2005) noted that the price of gas rose from $€ 3.05$ to $€ 5.70 / G J$. With approximately 8GJ used per unit of electricity produced, this clearly had a significant impact on the underlying electricity prices ex- $\mathrm{CO}_{2}$. In order to isolate the relative effects of gas price increases from the impact of $\mathrm{CO}_{2}$ pricing, Sijm et al. (2005, pp55-61) undertook extensive statistical analysis of the pass-through rate in Germany and the Nertherlands - those two systems being suitable representatives of the broader EU15 at the extremes. Their analysis of Germany found the pass-through rate to be 73 per cent in peak periods and 46 per cent in off-peak periods which implies a base load rate of only 58 per cent. The analysis for the Netherlands revealed 39 per cent in peak periods (predominantly gas fired generation setting peak prices) and 55 per cent in off-peak periods (predominantly coal plant setting off-peak prices) which implies a base load rate of 48 per cent. Accordingly, a number of coal plants would not have been remunerated adequately in the absence of permit allocation. And to the extent that coal plant did make supra-normal profits, such gains need to be separated between the allocation of permits, permits allocated to plant already ear-marked for closure, and the inherent rise in underlying electricity prices driven by sharply rising gas prices.

\subsection{Permit Allocation and the Time-Dimension of Supra-Normal Profits}

Apparent supra-normal profits need to be gauged carefully against investment benchmarks over sufficient time horizons. The pass-through rate of existing coal plant will deteriorate as gas plant, the preferred near-term new entrant under $\mathrm{CO}_{2}$ pricing, continues to be added to a power system. 
Consequently, it is entirely disingenuous to argue that because an individual coal generator earns supra-normal profits in one reporting period that a policy of permit allocation is somehow flawed. To see why this is the case, consider the scenario whereby a brown coal facility's useful economic life is reduced from 30 years to a period of say 7-10 years as a result of an ETS. The plant must lift its economic return from 11 per cent to 23 per cent per annum in order for its stock and bond holders to remain otherwise equal. ${ }^{3}$ Thus, what may prima facie appear to be intermediate-run supra-normal profits (that is, a return greater than 11 per cent but less than 23 per cent) may merely turn out to be at best, a modest and insufficient contribution towards the recovery of stranded capital.

Finally, an ETS, if left entirely to auction, would have the effect of creating crippling financial imposts on existing corporate and financial structures of power generators in Australia. Most fossil-fired generators would find it difficult to finance such an overwhelming annual impost. For example, at $\$ 17.50 / \mathrm{t}$ for $\mathrm{CO}_{2}$, a 2000MW brown coal generator in Victoria would have to raise finance of \$324 million per annum, equivalent to 10 per cent of its aggregate asset value or 55 per cent of its annual revenues, in order to pay for permits.

\section{The Requirement and Cost of New Generating Plant in Victoria}

The supply-demand balance in the NEM and in Victoria is 'tight'. In 2007/08 for example, NEM-wide system reserve, the spare generating capacity designed to protect against weather related demand surges and unexpected generating plant outages, was just 10.0 per cent compared to the world benchmark of 15.0 per cent reserve. The National Electricity Market Management Company (2007) (NEMMCO) predicts that planning reserves will fall to just 8.0 per cent by the start of the ETS in 2010 and that Victoria requires additional generating capacity in that year in order to ensure a reliable supply of electricity. To put this into perspective, throughout most of the NEM's history, reserve plant margins have been between 20 per cent and 40 per cent across the various regions (Simshauser 2005). At no time has the entire system-wide reserve been at or below 10 per cent during painful reforms. The NEMMCO forecasts are significant as they confirm that the Victorian power system is 'in-balance' vis-à-vis supply and demand and that as a result, the exercise of market power by incumbent generators is likely to be highly effective, as modeling results later in this article illustrate. The complete stock of plant in Victoria is listed in Appendix I along with the relevant demand-side statistics.

Victoria especially requires clarity over greenhouse policy. Consider Table 2, which provides a summary of the short run marginal cost and long run marginal cost of production of brown coal and Natural Gas Combined Cycle (NGCC) plant assuming base load duties, with and without $\mathrm{CO}_{2}$ pricing at $\$ 25 / t$ using the entry cost assumptions listed in Appendix 1:

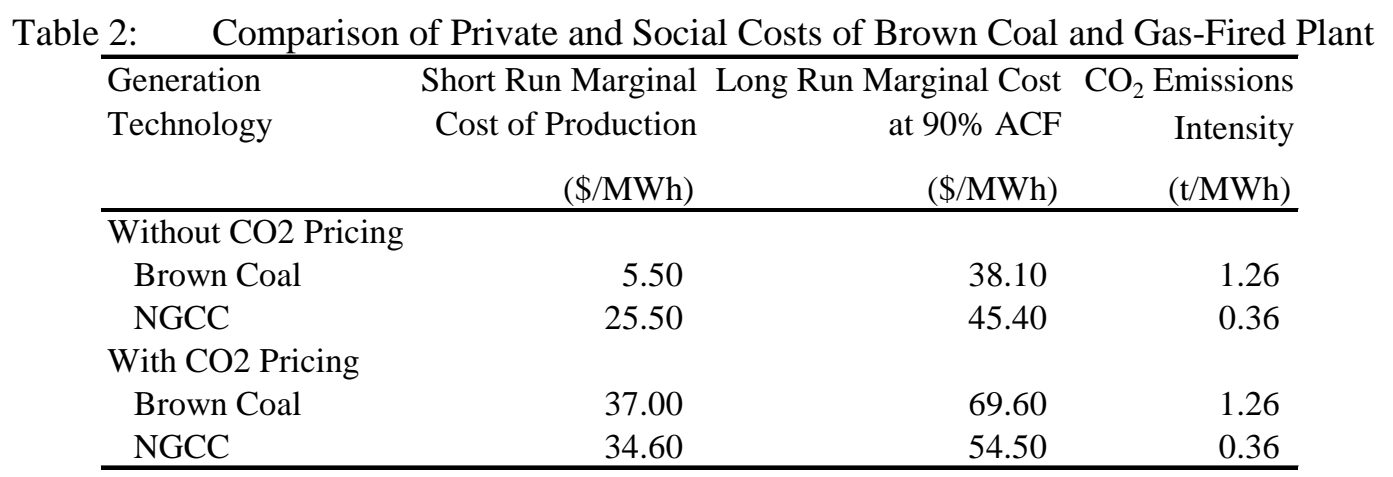

Table 2 clearly illustrates that in the absence of $\mathrm{CO}_{2}$ pricing, brown coal has a substantially lower short run marginal cost at just \$5.50 compared to \$25.50 for NGCC plant and lowest overall production cost at $\$ 38.10 / \mathrm{MWh}$. At the time of writing, with hedge contracts trading at about 
\$35-40/MWh, an NGCC plant with an average cost of \$45.40/MWh would not cover its costs when operating base load duties. However, when the social or environmental cost of production is included at an assumed $\mathrm{CO}_{2}$ price of (say) \$25/t under the ETS, the economics of the two newentrant power generating technologies reverses completely as shown in Table 3:

Table 3: Comparison of Social Operating Costs with $\mathrm{CO}_{2}$ Priced at $\$ 25 / \mathrm{t}$

\begin{tabular}{lrrr}
\hline $\begin{array}{l}\text { Generation } \\
\text { Technology }\end{array}$ & $\begin{array}{r}\text { Short Run Marginal } \\
\text { Cost of Production } \\
(\$ / M W h)\end{array}$ & $\begin{array}{r}\text { Long Run Marginal } \\
\text { Cost at 90\% ACF } \\
(\$ / M W h)\end{array}$ & $\begin{array}{r}\mathrm{CO}_{2} \text { Emissions } \\
\text { Intensity } \\
(\mathrm{t} / \mathrm{MWh})\end{array}$ \\
\hline Brown Coal & 37.00 & 69.60 & 1.26 \\
NGCC & 34.60 & 54.50 & 0.36 \\
Cost of Capital (\%) & 11.00 & & \\
\hline
\end{tabular}

Note that once $\mathrm{CO}_{2}$ is priced, NGCC plant becomes more competitive both in terms of its short run marginal cost (that is, spot market competitiveness) and in terms of its long run marginal cost (forward market competitiveness). This has been the historical dilemma of base load capacity investments in Victoria, until now.

\section{Pricing $\mathrm{CO}_{2}$ Emissions and Defining the Victorian Tipping-Point}

The economics of brown coal generation means that in the absence of environmental pricing, these facilities completely dominate the aggregate supply function both in Victoria and the NEM more generally. Figure 1 provides a static representation of the aggregate supply curve of all plant in the Victorian region of the NEM. In this static supply curve, in which all plant is assumed to be fully available and offered to the market at short run marginal cost, note that the 'marginal' brown coal generator is located in the $4500 \mathrm{MW}$ to $6000 \mathrm{MW}$ quantity area. Imports from NSW, when undertaken competitively, cannot compete with the brown coal generation fleet and hence tend to withdraw to higher prices. Additionally, a new entrant NGCC plant cannot compete at the margin with either of the Victorian brown coal fleet or the NSW black coal fleet which explains why there is no NGCC plant on the system operating base duties at present.

Figure 1: Aggregate Supply Curve in Victoria (Private Cost Basis) 


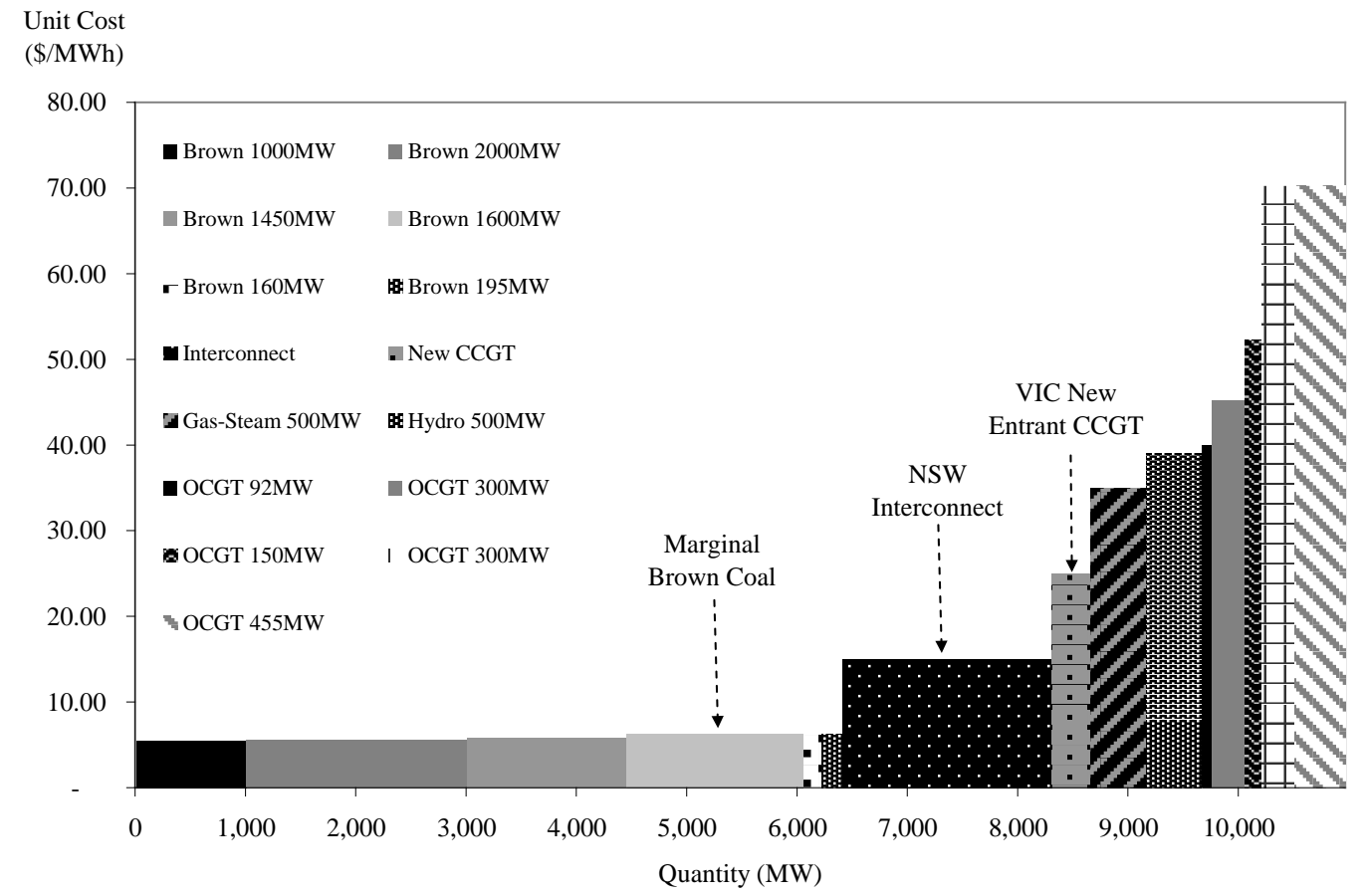

The static analysis of the supply curve in Figure 1 focuses on 'private marginal cost' and not 'social marginal cost' (that is, including environmental costs arising from an ETS). When social costs are combined with the private cost of production, the power station 'order-of-merit' changes significantly in Victoria. An important input to the subsequent modelling in this article is the assumed cost of $\mathrm{CO}_{2}$ emissions that generators must factor into their social marginal cost. For the purposes of this article, the exogenously determined price has been defined as the cross-over point or tipping-point for which coal and gas plant will reverse in the order-of-merit at the margin. ${ }^{4}$ This can be established by reference to the short run marginal cost of the marginal brown coal plant relevant to an efficient new entrant NGCC plant. Since the marginal brown coal plant emits about 1.5t/MWh and NGCC plant emits about $0.4 \mathrm{t} / \mathrm{MWh}$, and given private marginal costs of $\$ 5.50$ and $\$ 25.50$ respectively (from Table 2), when $\mathrm{CO}_{2}$ is priced at $\$ 17.50 /$ t or greater, a fundamental change in dispatch is likely to occur in the Victorian region. ${ }^{5}$ This is due to two primary changes in the aggregate supply function. First, at $\$ 17.50 / \mathrm{t}$ the marginal brown coal producer in Victoria will slip behind a new entrant gas fired plant in terms of merit position. Second, once $\mathrm{CO}_{2}$ is priced above $\$ 16.00 / \mathrm{t}^{6}$, the entire NSW fleet of black coal generators becomes more competitive than the marginal brown coal producer in Victoria. Thus at this juncture, one would reasonably expect the NSW region to shift from a nett-importer of power from Victoria to a nett-exporter of power to Victoria. The static supply-side impact is illustrated in Figure 2.

Figure 2: Aggregate Supply Curve in Victoria (Social Cost at \$17.50/t) 


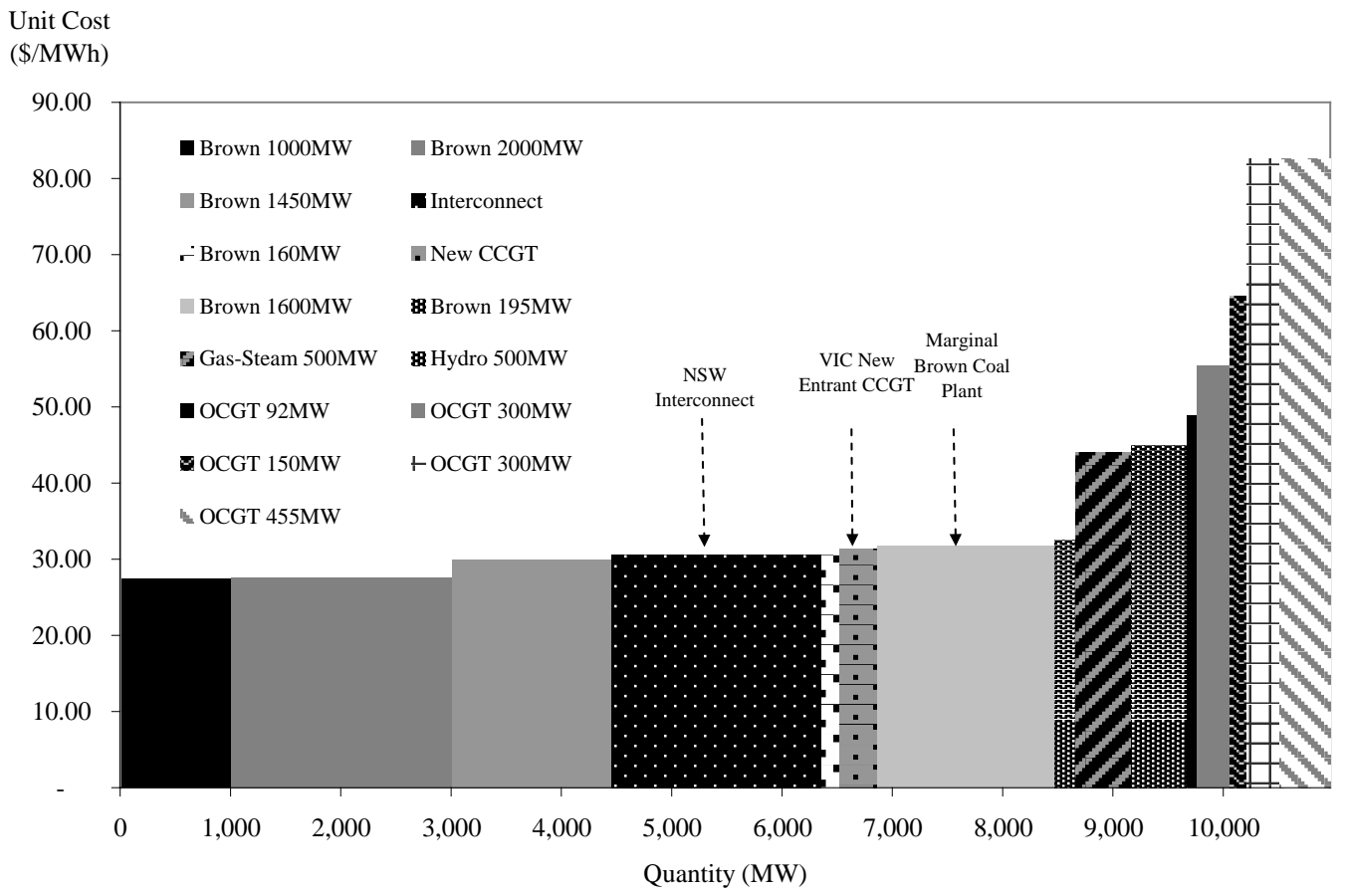

Perhaps the more significant event associated with the tipping-point is the NSW Interconnect. Currently, the NSW coal fleet operates at an annual capacity factor (ACF) of 61.7 per cent which is well below design levels. Subject to any coal supply constraints, the NSW plant stock is capable of increasing output levels to an ACF of 85-90 per cent at the expense of the marginal brown coal generator in Victoria. Similarly, NGCC plant is also able to undercut the marginal brown coal generator in Victoria, causing the latter to operate at much reduced output. This unsustainable loss of profitability will be examined in the next section.

\section{Modelling Simulation Results}

In order to quantify wealth transfers arising from an ETS, it is necessary to establish a Base Case Scenario. But before examining the simulation modeling results from this calibration case, it is first worthwhile to provide a brief overview of the NEM market institutions because they have material implications under an ETS.

\subsection{NEM Spot Market}

The NEM is classed as an energy-only, mandatory gross pool, uniform first-price auction market. The market is centrally coordinated by a power exchange (NEMMCO) which assembles capacity offers from all generators in the market and forms an aggregate supply function in continuous five-minute intervals throughout the year. It is an 'energy-only market' because generators only receive payment for the electricity they produce. It is a 'mandatory gross pool' because all energy produced 'must' be supplied through the spot market in the first instance. The uniform first-price auction mechanism (that is, a marginal price-clearing market as opposed to a pay-asbid) ensures that demand and supply is cleared within the spot price range, between $-\$ 1000$ to the ceiling price of $\$ 10000 / \mathrm{MWh}$. Typically, the average annual spot price is $\$ 30-\$ 40 / \mathrm{MWh}$. Generators may offer supply curves with up to 10 price-quantity combinations per generating unit per half-hour. The number of combinations is material because, being a uniform first-price auction design, successful infra-marginal capacity offers are remunerated at the higher (marginal) clearing price. 


\subsection{Financial Markets Used by NEM Participants}

Given the potential for extreme spot price volatility, participants manage the risks associated with their NEM physical positions by entering into conventional financial market hedge contracts to lock-in forward prices. The most widely traded instruments are electricity commodity swaps and electricity commodity call options (or 'caps'). Swaps are the most commonly traded and can be for 24 hours-a-day (flat swap), for the traditional peak demand period between 7am and 10pm (peak swap) or for any other agreed time period. As the name implies, cap contracts allow the holder to set an upper limit on the price that they will pay for electricity, that being the strike price. No matter how high the spot price of electricity may rise, the maximum price the holder will pay for electricity covered will be the cap price. In exchange, cap purchasers pay a fee, known as the 'cap premium', for the privilege.'

\section{3 $\quad \mathrm{CO}_{2}$ Intensity of Victoria's Generators}

Victoria is predominantly serviced by indigenous brown coal generators, with a small amount of gas and renewable capacity. Interconnection with surrounding states brings in supplies from black coal as well as renewable energy. Figure 3 provides an illustration of the relative cost impact generating plant in Victoria when $\mathrm{CO}_{2}$ is priced at $\$ 25 /$. Note that the $\mathrm{CO}_{2}$ intensity of brown coal ranges from 1.26 to $1.5 \mathrm{t} / \mathrm{MWh}$ which is significantly higher than NGCC plant at $0.4 \mathrm{t} / \mathrm{MWh}$. Also included in Figure 3 are two horizontal lines; the first representing the $\$ 25 / \mathrm{t}$ price of $\mathrm{CO}_{2}$, and a second line at an assumed 70 per cent pass-through of the $\mathrm{CO}_{2}$ price. 
Figure 3: Relative $\mathrm{CO}_{2}$ Intensity of Generators Supplying Victoria

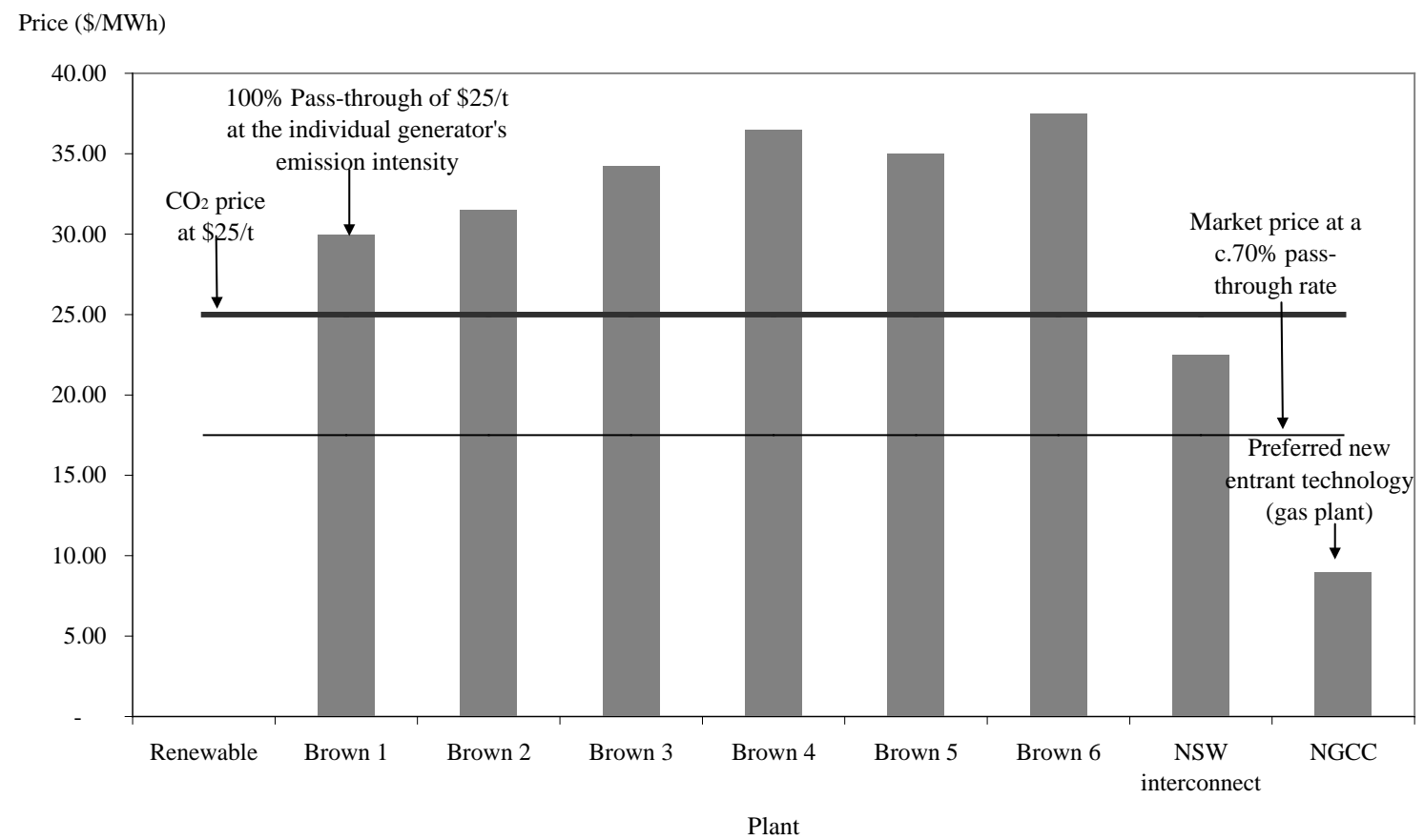

The chart shows that once the cost of a $\$ 25 / \mathrm{CO}_{2}$ emission liability is factored in the cost of production, the cost competitiveness of brown coal generators are all very adversely affected by comparison to black coal (NSW Interconnect), NGCC and renewable technologies.

\subsection{The Base Case Scenario}

Supply- and demand-side information from Calendar Year $2006^{8}$ Victoria has been entered into a dynamic partial equilibrium model of the power system called NEMESYS, along with the economic and technical parameters of the complete stock of incumbent plant in the region. A detailed description of NEMESYS is provided in Simshauser (2008) and as noted earlier, all supply and demand-side information, including economic and technical parameters, are listed in Appendix I. The $1900 \mathrm{MW}$ interconnect, modeled in an identical manner to a pumped-storage scheme, simulates the economic power transfers between Victoria and New South Wales. ${ }^{9}$ Exports from Victoria to NSW are assumed to apply whenever available Victorian brown coal plant capacity exceeds local demand. In NEMESYS, half-hourly demand is met by drawing upon the available plant stock in a pure economic cost order as per the NEM Rules. And similarly, half-hourly equilibria are determined using three-shot capacity offers by generation plant under similar conditions to the NEM. Summary level modelling results of the brown coal fleet under the Base Case Scenario are provided in Table 4, while higher resolution financial data is provided in Figure 4. 
Table 4: $\quad$ Base Case Scenario Plant and Market Statistics

\begin{tabular}{lc}
\hline Plant Statistics & Brown Coal Fleet \\
\hline Market Share (\%) & 93.2 \\
Capacity Factor (\%) & 91.0 \\
Gross Margin (\$M) & 1,620 \\
Emissions (Mt) & 63.8 \\
\hline Market Statistics & Annual Average \\
\hline CO2 Price (\$/t) & - \\
Spot Price (\$/MWh) & 34.19 \\
Swap Price (\$/MWh) & 38.44 \\
\$100 Cap Premium (\$/MWh) & 12.50 \\
\hline
\end{tabular}

Note that the brown coal fleet has a Victorian energy market share of 93.2 per cent - thus completely dominating the supply-side in that region. The plant stock operates at an ACF of 91.0 per cent. The gross margin (that is, spot and forward electricity revenues less variable production costs) of the brown coal fleet is $\$ 1.62$ billion and emissions, which are un-priced, equate to around 63.8Mt per annum. The average spot price from the simulation model is $\$ 34.19 / \mathrm{MWh}$, which compares favourably with the actual historical 2006 result of \$34.08/MWh. Flat swaps are assumed to trade at $\$ 4.25$ above spot, at $\$ 38.44 / \mathrm{MWh}$. Cap contract premiums are assumed to trade at $\$ 12.50 / \mathrm{MWh}$ in exchange for a $\$ 100$ strike price. The individual Gross Margins for the primary installations in the Victorian region under the Base Case Scenario are reproduced in Figure 4, with Economic Returns calibrated against the long run marginal cost assumptions set out in Table 2.

Figure 4: Gross Margins and Economic Returns in the Base Case Scenario

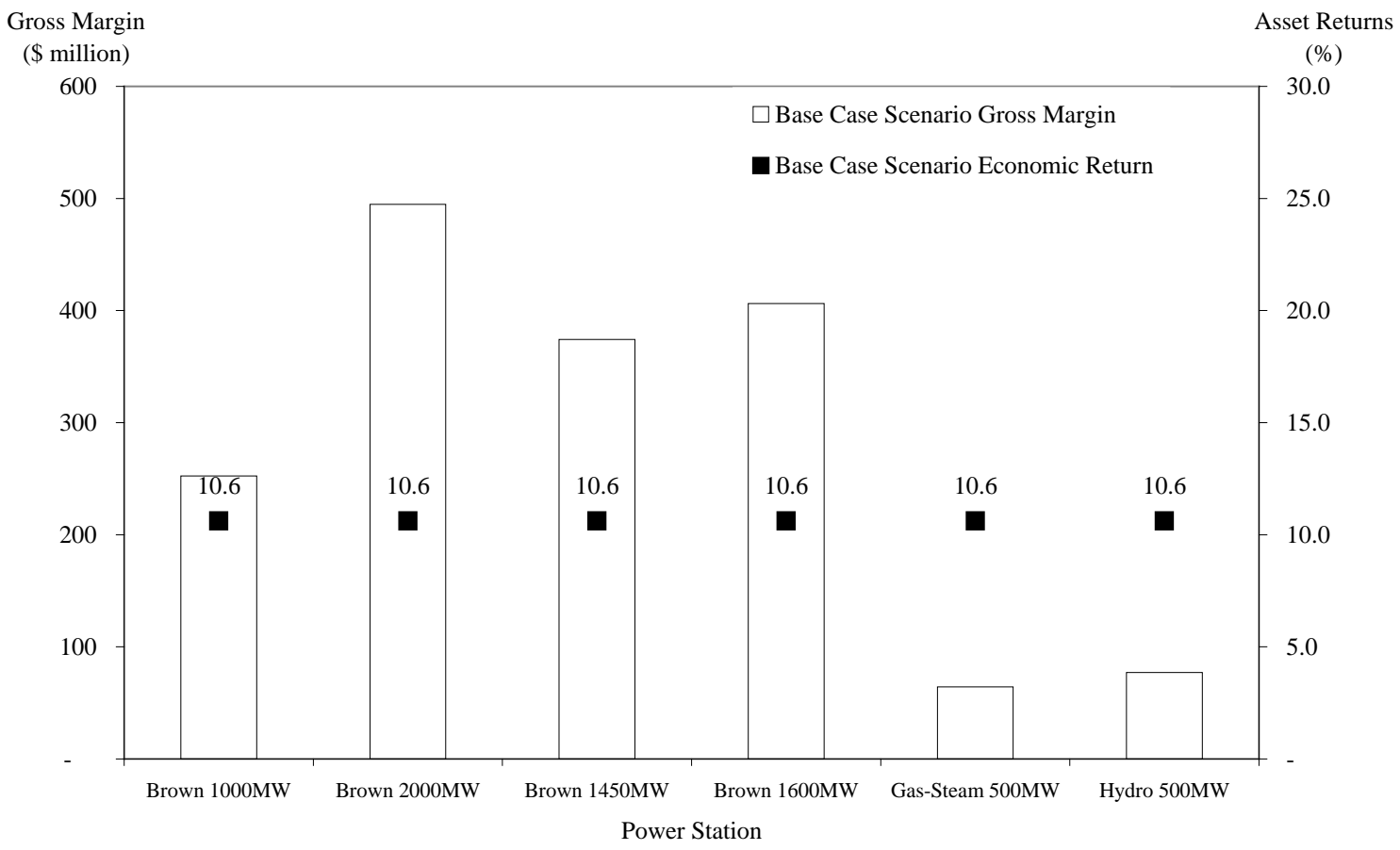

Thus, the Base Case Scenario has been established, and it is now appropriate to introduce an ETS, whereby permits are assumed to be auctioned to incumbents.

\subsection{On Wealth Transfers and the Tipping-Point Scenario}

In this next scenario, the NEMESYS Model has been adjusted to account for a $\mathrm{CO}_{2}$ price at the Tipping-Point value of $\$ 17.50 / t$ defined previously. This has the effect of altering the supply-side in Victoria as illustrated in Figure 2, whereby the marginal brown coal generator finds itself 
dislocated by the reversal of interstate flows between Victoria and New South Wales, and in future by new NGCC plant. The results of the simulation modelling are illustrated in Table 5:

Table 5: $\quad$ Tipping-Point Scenario Plant and Market Statistics

\begin{tabular}{lrrr}
\hline Coal Plant Statistics & Base Case & Tipping-Point & Change \\
\hline Market Share (\%) & 93.2 & 80.8 & -12.4 \\
Capacity Factor (\%) & 91.0 & 78.9 & -12.1 \\
Gross Margin (\$M) & 1,620 & 1,258 & -362.3 \\
Emissions (Mt) & 63.8 & 54.7 & -9.1 \\
\hline Market Statistics & & & \\
\hline CO2 Price (\$/t) & - & 17.50 & 17.50 \\
Spot Price (\$/MWh) & 34.19 & 51.82 & 17.63 \\
Swap Price (\$/MWh) & 38.44 & 56.07 & 17.63 \\
\$120 Cap Premium (\$/MWh) & 12.50 & 16.00 & 3.50 \\
\hline
\end{tabular}

In Table 5, the Base Case Scenario results for the brown coal fleet have been reproduced in Column 2, while the Tipping-Point Scenario results are presented in Column 3. The difference between the two scenarios is presented in the final column. Note from Table 5 that the market share of brown coal has dropped significantly, from 93.2 per cent to 80.8 per cent, a change of 12.4 per cent. Victoria has also shifted from being a nett-exporter of energy, production being 104 per cent of local demand, to a nett-importer of energy where local production represents 87 per cent of local demand. The average ACF for brown coal plant has fallen from 91.0 per cent to 78.9 per cent, with the majority of the reduction being borne by the marginal brown coal generator, where its ACF has dropped from 90 per cent to less than 60 per cent. The combined commodity and emissions market effectively forcing the marginal brown coal generator to shift from base to mid-merit duties. The Gross Margin of the brown coal fleet has fallen by $\$ 362.1$ million and emissions have fallen by 9.2Mt per annum. The average spot price from the simulation model is $\$ 51.82 / \mathrm{MWh}$, which is up $\$ 17.63 / \mathrm{MWh}$ and is now marginally above the post- $\mathrm{CO}_{2}$ new entrant NGCC price of $\$ 51.75 / \mathrm{MWh}$. The pass-through rate of the $\mathrm{CO}_{2}$ cost impost to electricity consumers is 78 per cent. This is a significant result as it implies that 22 per cent of the cost of $\mathrm{CO}_{2}$ is being borne by 'generators as a class'. Importantly, the 'incidence of tax' is being borne in a very disproportionate manner amongst Victorian generators. At one extreme, the gas-fired and hydro portfolios extract supra-normal profits from the rise in wholesale prices. Others incurred significant financial losses, especially the marginal brown coal plant which passed-through just 58 per cent of the $\mathrm{CO}_{2}$ cost impost. Gross margins for the primary installations in the Victorian region under the Tipping-Point Scenario are reproduced below in Figure 5, with economic returns calibrated against the Base Case Scenario. 
Figure 5: Gross Margins and Economic Returns in the Tipping-Point Scenario

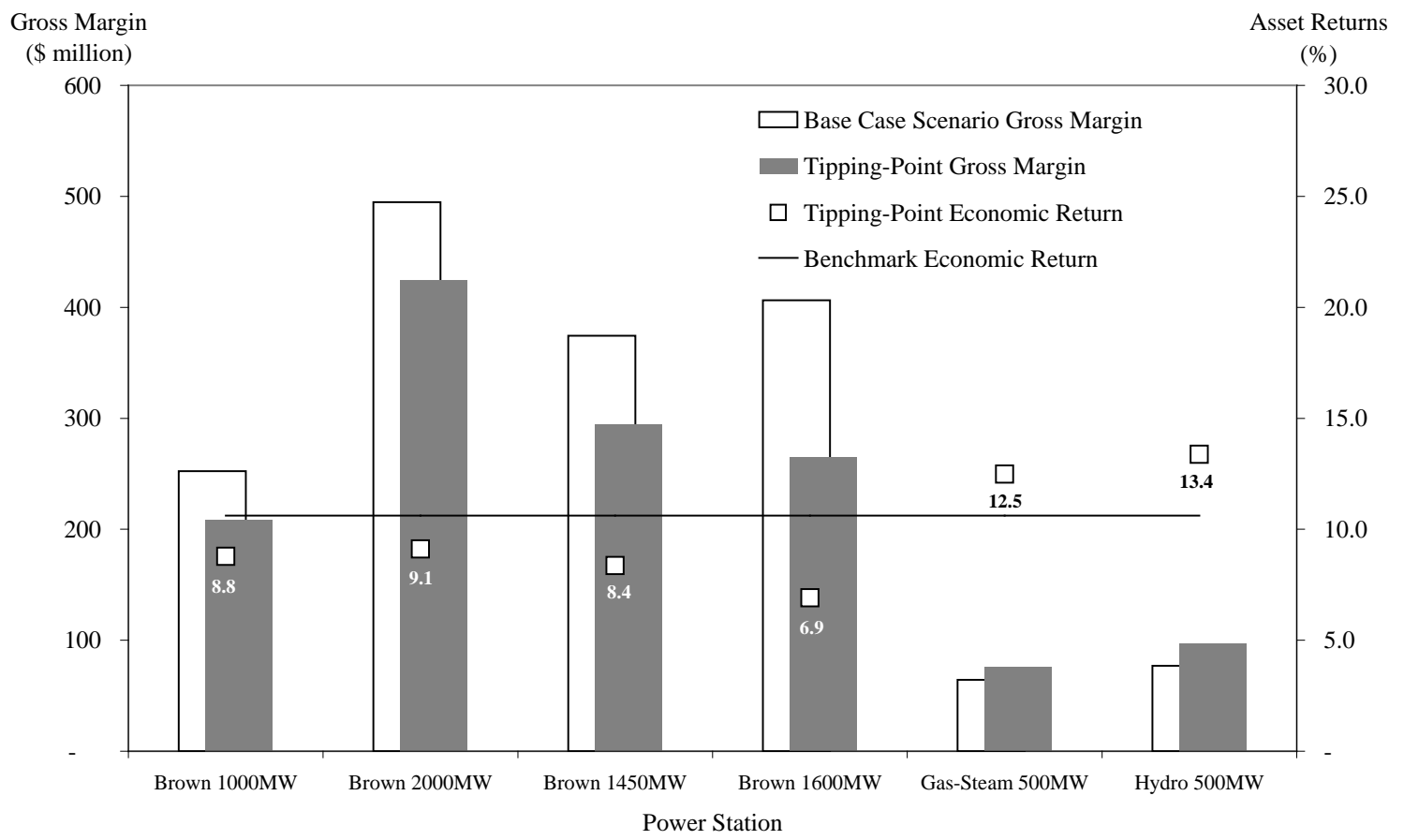

Note that the economic returns of the brown coal generators have deteriorated significantly, from 10.6 per cent in the Base Case Scenario to a fleet average of 8.3 per cent in the Tipping-Point Scenario. To put this into perspective, the brown coal asset base is approximately $\$ 10.2$ billion in aggregate. The present value of wealth transfers at a constant 8.3 per cent return equates to $\$ 3.5$ billion - a shift of 34 per cent.

A key issue at this juncture is whether the burden of the incidence of tax on coal generators actually represents a problem. One reviewer of this article raised this very issue (at least until the contents of Section 6 were revealed). There is no doubt that the full effect of the tax should be bourne by plant and the closure of coal plant should occur as the ETS market dictates in order to ensure that environmental policy objectives are achieved. The real question is whether the generating firms survive beyond their (stranded) generating plant. Any allocation of permits should be completely fungible so that they do not become 'production subsidies'. In this way, inefficient generating plant may close while the allocated permits can be utilized to satisfy outstanding debt obligations and a recycling of plant capital into new (lower emitting) replacement plant. Thus, permit allocation should be classed as industry structural adjustment assistance, and not a production subsidy.

An ETS represents an extremely painful microeconomic reform. Most business economists in Australia acknowledge that this will be the most significant policy change in Australia in five decades, and will lead to profound structural changes in power generation (Ergas 2008). While Argy (1999) has noted that economic literature generally commences the analysis of any reform with the notion that government must be able to govern, he highlights that there are certain conditions where structural adjustment assistance is desirable or necessary. When these conditions bind invariably comes down to a case for government intervention on economic efficiency grounds if a reform is likely to lead to a material misallocation of resources. Argy (1999) has argued that an industry should qualify for structural adjustment if reform shocks are large, policy driven events, breach long standing expectations, and are likely to produce uneven net benefits or disproportionate losses. The situation facing power generators seems consistent 
with these conditions. But most importantly is the potential for a material misallocation of resources - for in the absence of an allocation of emission permits to the marginal brown coal generator (aimed at stabilizing its relative economic value), the origins of the 'Wounded-Bull Scenario' emerge.

\section{The Wounded-Bull Scenario - a Final Period Exit Strategy}

In the previous section, emission permits were assumed to be auctioned at $\$ 17.50 / t$ and the marginal brown coal generator found its annualised financial returns at sub-optimal levels, at just 6.9 per cent. In terms of Gross Margin, the marginal brown coal generator's result dropped from about $\$ 400$ million to $\$ 260$ million, a loss of more than $\$ 140$ million in a single year.

Yet this is only the start of the losses that can be expected by the marginal brown coal generator. As new, high-efficiency NGCC plant begins to enter, the $\mathrm{CO}_{2}$ price pass-through rate of coal plant will decrease further. In a sensitivity case, modelling results from NEMESYS indicate that the current market pass-through rate of 78 per cent would drop to about 60 per cent for generators as a class following the first new entrant NGCC plant instalment. The pass-through rate for the marginal brown coal generator would drop from 58 per cent to 42 per cent. This makes intuitive sense because the percentage of time that spot electricity prices are set by high emissions intensity coal plant will decline as new low emissions intensity NGCC plant appears in the aggregate supply function. Recall that NGCC plant do not need to pass-through more than $0.4 \mathrm{t} / \mathrm{MWh}$ into wholesale pricing.

To that end, the financial impact of a 350MW NGCC plant instalment added to the Tipping-Point Scenario sends the marginal coal generator's Gross Margin from \$260 million down to just \$150 million, with economic returns collapsing from 6.9 per cent to less than 4.0 per cent. This result is very significant. At a 4 per cent return the marginal generator shifts to a position of genuine financial distress through a failure to service its debt and thus in a relatively short period of time the plant will face bankruptcy. ${ }^{10}$ More importantly, the outlook only gets worse as more NGCC plant inevitably arrives. Thus, in facing this eventual prospect, the marginal brown coal generator becomes a 'Wounded-Bull' in the electricity spot market and a 'final period exit strategy' envisaged in King (1998) becomes entirely predictable.

The marginal brown coal generator must, by any measure, seek to extract its stranded asset base from the spot electricity market as quickly as possible. Development of an NGCC plant takes around 5-6 years. It will take approximately 4-5 NGCC machines to effectively wipe-out the marginal brown coal generator's market presence, demand growth notwithstanding. Depending on development permitting delays, equipment lead-order times and construction lags, the Wounded-Bull will have between 7-10 years before it is completely over-run by the new entrant NGCC machines. Thus it has approximately 7-10 years in which to recover its entire 30+ year investment returns if adequate emission permits are not allocated.

\subsection{The Economic Withdrawal of Generating Capacity}

The precedence for strategic behaviour by generators in the NEM by economically withholding generating capacity in order to drive up spot electricity prices has long existed - in theory and in practice. Simshauser (1998) demonstrated that, in theory, the dominant base load generator in Victoria could economically withhold 30 per cent of its capacity from the spot market and shift spot electricity prices substantially above competitive levels (that is, closer to long run marginal cost) whilst simultaneously increasing the profits of the firm. However, important conditions were necessary in order for such a strategy to be profit maximising for the generator. Using simulation modelling, the results in Simshauser (1998) revealed an important order of execution; before a firm withholds generating capacity from the spot market, it must first unwind any hedge positions associated with that capacity earmarked to be withheld, and that capacity which is to benefit from higher spot prices. This is necessary so that the firm does not have subsequent exposures to hedge contract payments following spot price increases. 
This theory of economic withholding of generating capacity in Victoria was prosecuted with virtual text-book precision by a dominant base load producer over the summer of 2000/01, whereby approximately 30 per cent of their capacity was withheld from the spot market. This had the effect of driving spot prices from about $\$ 18$ before capacity withholding, to about \$45/MWh after capacity withholding (Simshauser 2008). That this occurred was not at all surprising on two counts. First, the pre-withholding spot and forward electricity prices were about 50 per cent below the long run marginal cost of \$35-40/MWh; and second, if the market remained unchanged, a number of generators would have faced financial distress. ${ }^{11}$ This strategic behaviour has been well documented in AGL v ACCC (French 2003).

\subsection{The Wounded-Bull Scenario}

Recall from Section 3 that the Victorian power system is currently 'in balance' and new entrant plant has not yet been committed. Thus the economic withholding of capacity is a credible strategy. If a dominant brown coal generator was able to execute a strategy of economic withholding of capacity in an environment of chronic base plant oversupply in 2000/01 and drive material increases in spot and forward prices, it is not difficult to imagine what a similar sized generator might achieve in a tightly-matched market. Prices could be lifted substantially above long run marginal cost. Thus, while the emissions market is highly unfavourable to coal generators in the absence of a suitable allocation regime, the commodity market facing the Wounded-Bull is highly favourable because there is unlikely to be an oversupply of generating capacity. In this Wounded-Bull Scenario, we assume that the marginal coal generator in Victoria reduces its hedge cover from approximately 80 per cent of installed capacity to 20 per cent of installed capacity to provide the firm with maximum flexibility in the spot market (but conversely, heightened risk exposure to uncertain spot price outcomes). This is markedly more aggressive than in Simshauser (1998) and in French (2003).

In the NEMESYS Model, the spot market behaviour of the marginal brown coal generator in Victoria is altered to drive imbalances into electricity spot commodity prices. Specifically, a minimum production load of 45 per cent of the $1600 \mathrm{MW}$ generating plant's capacity is maintained continuously, but infra-marginal quantities of the marginal brown coal generator are progressively withdrawn from base load prices (that is, below $\$ 20 / \mathrm{MWh}$ ) to the market price cap of $\$ 10$ 000/MWh. This has been done through iterative dynamic power system simulation modelling, starting at the withdrawal of just 5 per cent of capacity through to 55 per cent of capacity withdrawn (that is, withdrawn up to the minimum production load of 45 per cent). As more and more capacity is progressively withheld from the spot electricity market, it has the effect of reducing quantity produced but drive clearing prices to higher levels. When the quantity withheld by the marginal brown coal generator actually binds in the NEM's uniform first-price auction, it sends the spot market price to the ceiling value of $\$ 10000 / \mathrm{MWh}^{12}$ In order to determine the dominant economic withholding strategy, these plausible outcomes between 5 per cent and 55 per cent were simulated and the effect on the marginal brown coal generator's gross profit was calculated in the NEMESYS Model with $\mathrm{CO}_{2}$ priced at $\$ 17.50 /$ t. The price-volume trade-off frontier is clearly depicted in Figure 6: 
Figure 6: Dominant Exit Strategy of the Marginal Brown Coal Generator

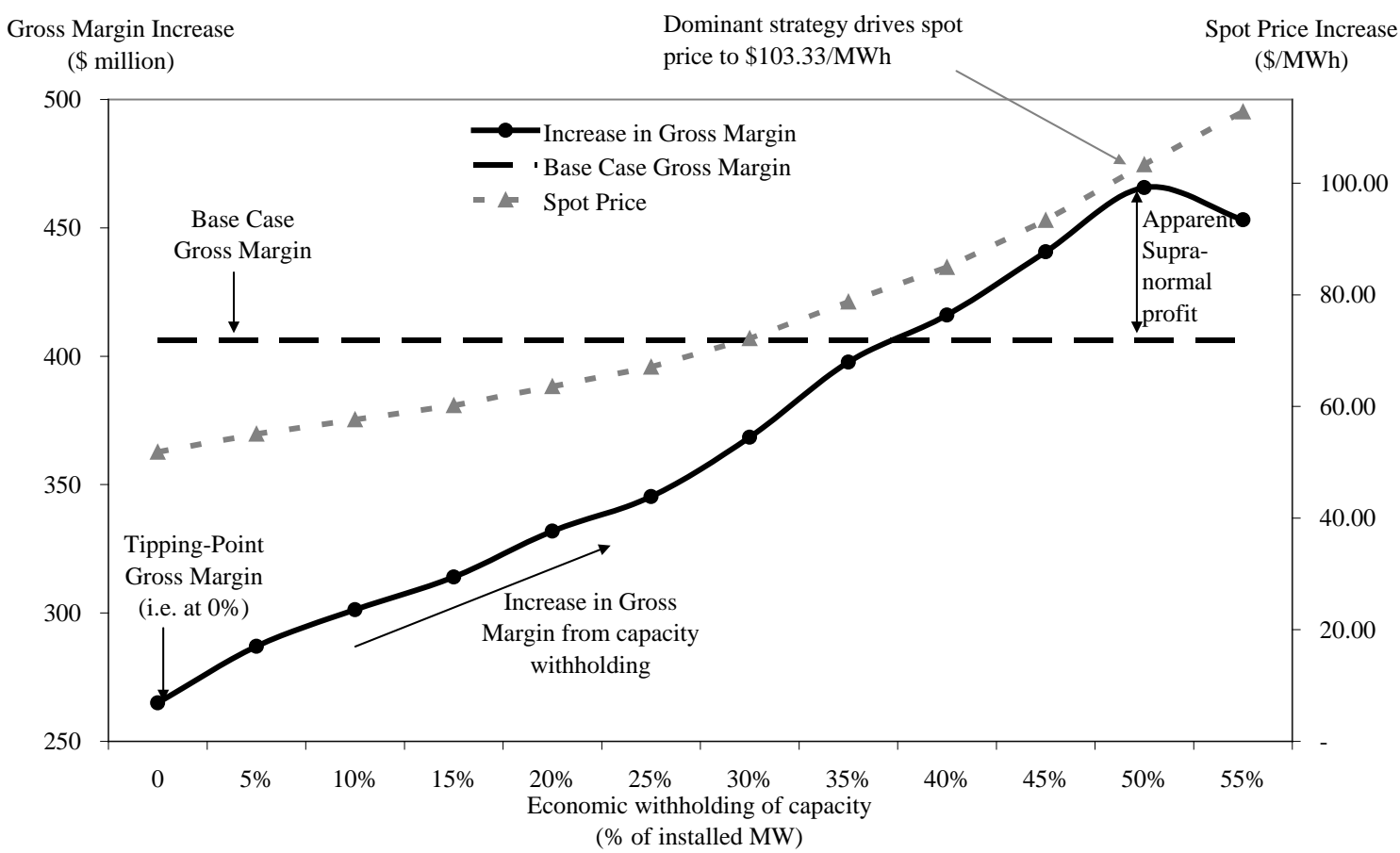

In Figure 6, the x-axis measures the extent to which the marginal brown coal generator economically withholds its capacity from the spot electricity market, from 0 per cent of its installed capacity to 55 per cent of its installed capacity. Three important lines are plotted and measured on the left and right y-axis. The first (dashed horizontal) line is the Gross Margin result from the Base Case, measured on the left y-axis and is plotted at just over $\$ 400$ million. The second (solid) line is the plausible Gross Margin outcomes of the marginal brown coal generator for a given level of capacity withholding from the spot market, and is also measured on the left yaxis. The first point in this series is where 0 per cent generating capacity is withheld and equates to a Gross Margin of \$260 million, that is, equivalent to the Tipping-Point Scenario. As generating capacity of the marginal brown coal generator is progressively witheld from the spot electricity market, spot prices increase and so too does the Gross Margin of the marginal generator. Note that the Gross Margin simulations peak at slightly below 50 per cent of capacity withheld. If more than 50 per cent of generating capacity is withheld from the market, spot prices continue to rise but from a Gross Margin perspective, it produces a diminishing return to the marginal generator because of the quantity loss. The final (dotted) line is the average system spot price and is measured on the right y-axis. Again, as generating capacity is withheld, spot prices rise from $\$ 52 / \mathrm{MWh}$ at 0 per cent generating capacity withholding to about $\$ 110 / \mathrm{MWh}$ with 55 per cent of generating capacity withheld.

In aggregate, the optimal outcome for the marginal brown coal generator is to withhold almost 50 per cent of its capacity and drive prices to about \$103/MWh. This represents a 300 per cent increase in the wholesale price of power from 2006 levels, and can be targeted by the marginal brown coal generator for the duration of its remaining economic life, which the authors would suggest as being of the order of 7-10 years. Based on the results contained in Figure 6, it is reasonable to assume that this is the dominant strategy for the marginal brown coal generator when permit policy is based on an all-auction approach rather than partial transitional allocation.

At one level, it might be tempting to argue that this represents an abuse of market power and would thus become of central focus to the Australian Competition and Consumer Commission. 
However, the supra-normal profits in Figure 7 are illusory because the firm must now extract its economic returns over a 7-10 year period rather than a 30-year period. As noted in Section 2, the economic returns over 30-year period at 11 per cent convert to an annualised return of 23 per cent over a 7-10 year period. Figure 7 clearly demonstrates that from an economic perspective, even with such extreme market prices, this is only mildly profitable by comparison to the Base Case Scenario, and most importantly, under no conditions could it be said that the marginal brown coal generator is extracting economic rent since its returns are substantially below 23 per cent.

Figure 7: Gross Margins and Economic Returns in the Wounded-Bull Scenario

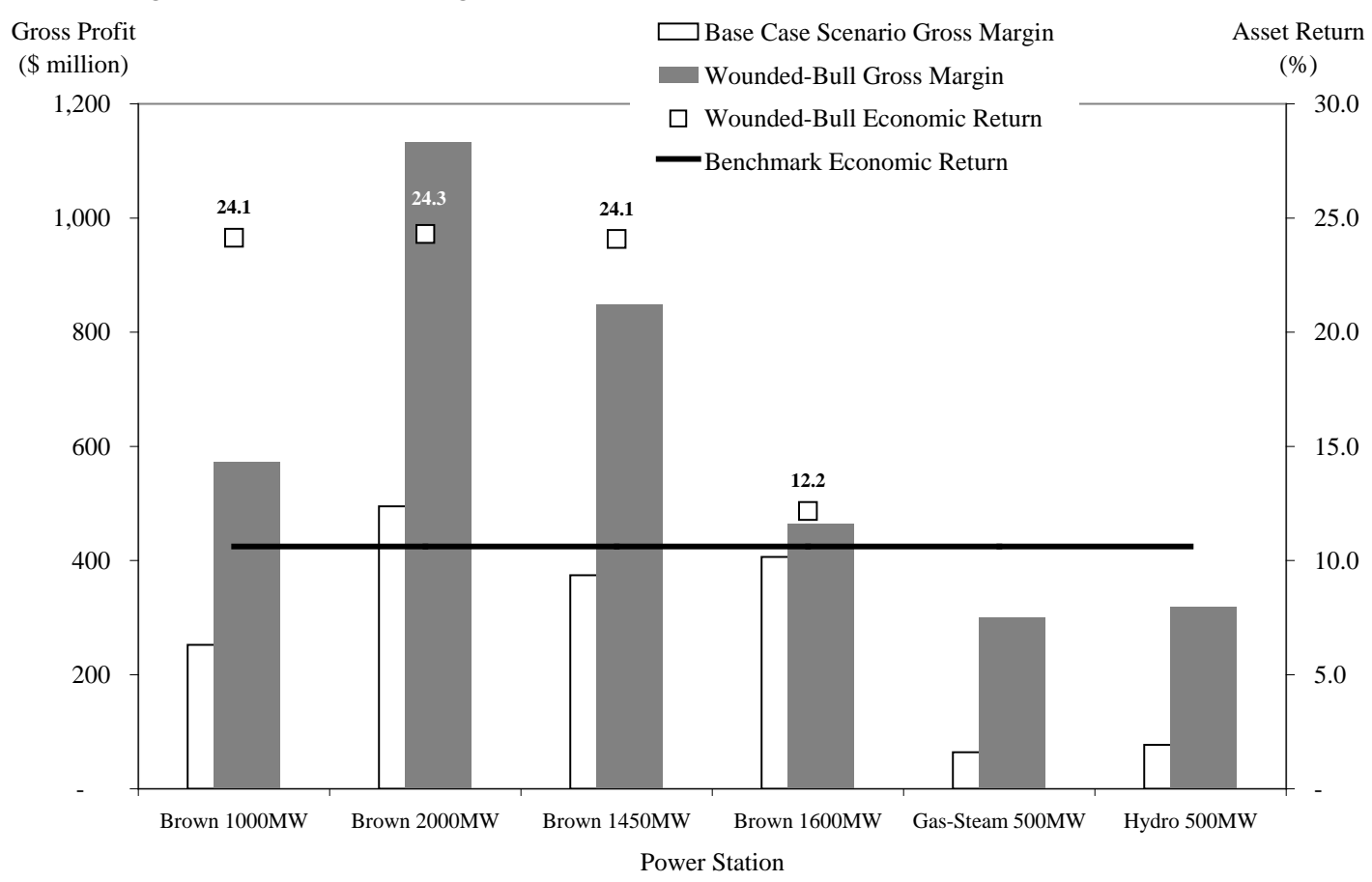

From the marginal brown coal generator's point of view, increasing the economic returns of the firm from 6.9 per cent to 12.2 per cent at an annual gain of \$200 million is most certainly a worthwhile feat and therefore an entirely predictable outcome. Interestingly, the remaining brown coal generators do earn returns of circa 23 per cent, and thus will be able to reclaim a majority of their stranded investment if the Wounded-Bull persists over the exit period. Consequently, the brown coal fleet is very likely to tacitly support the Wounded-Bull's spot market tactics, albeit carefully. But NGCC plant will enter the market and gradually devour the intermediate-run supra-normal profits. If the stranded generator is the only participant to gaming strategies, it will recover, at best, around \$300 million or 14 per cent of its $\$ 2.2$ billion sunk investment over the ensuring 7-10 year exit period. ${ }^{13}$

To be sure, investors in generating assets do not favour an environment that resembles gambling in order to recover asset values. Investors accept and adequately price a degree of uncertainty and supply-side shocks in power generation investments. But the potential ramifications of a poorly guided ETS permit allocation policy would certainly not fit inside these parameters. In addition, if power generators suffer substantive wealth transfers, at best, the cost and terms of debt and equity capital will rise significantly just as debt capital did following the spot electricity price collapse of the late 1990s, in turn leading to a higher cost of power. This factor has not been included in the current analysis.

So what are the welfare implications of substantial price spikes in one of societies' essential commodities? Shifting the spot electricity price from \$34/MWh to more than \$100/MWh, albeit 
on a temporary basis, will have a variety of welfare impacts. Notwithstanding the economic losses that will be incurred by the marginal brown coal generator when it is eventually squeezed out of the market (that is, approximately 70-80 per cent of its investment value), end-user electricity prices will invariably increase to alarming levels by Australian standards. And end-use consumers who can least afford an increase in electricity tariffs will be most affected, as noted by Parry et al. (2005). Clearly, policy makers will need to address this issue prior to it occurring. Intriguingly, a Wounded-Bull Scenario would lead to infinitely greater supra-normal profits to all other generators in all regions through interconnector flows and higher spill-over electricity prices than would an incorrectly applied (viz. EU15) policy of permit allocation.

\section{Conclusions}

The purpose of this research was to investigate the potential wealth transfers in the power generation industry that might arise under an emissions trading regime in the absence of a permit allocation policy. A key finding in this research was that coal generators will not be able to pass through 100 per cent of the $\mathrm{CO}_{2}$ cost impost due to the wide range of emission intensities amongst generating plant technologies. Quantitative results from Germany and the Netherlands indicated that the pass-through rate was less than 60 per cent. Simulation modelling results for Victoria suggested near-term pass-through rates as high as 78 per cent initially, but the addition of a single NGCC plant saw this number reduce to 60 per cent. Consequently, this suggests that in the absence of the permit allocation, coal generators will face non-trivial wealth transfers as new gas generating plant is inevitably commissioned.

The introduction of a $\$ 17.50 / t$ price for $\mathrm{CO}_{2}$ with emission permits assumed to be auctioned was found to drive substantial wealth transfers. Brown coal generator average returns dropped from 10.6 per cent to 8.3 per cent and the aggregate wealth transfer totalled $\$ 3.5$ billion or 34 per cent of the $\$ 10.2$ billion asset base at a 78 per cent pass-through. The combined commodity and emission price was noted to exceed the new entrant cost for an NGCC plant, and thus when a single new NGCC machine was added to the plant stock, the marginal brown coal generator's returns dropped from 6.9 per cent to below 4 per cent. The significance of this result was that the $\$ 2.2$ billion marginal brown coal generator would, at that juncture, face imminent financial distress. Thus were the origins of the Wounded-Bull Scenario.

In this scenario, the economic withholding of capacity by the marginal brown-coal generator was simulated which in turn caused spot electricity prices to rise above $\$ 100 / \mathrm{MWh}$ - a 300 per cent increase on the Base Case Scenario (nil $\mathrm{CO}_{2}$ cost) and 100 per cent increase over the TippingPoint Scenario (with $\mathrm{CO}_{2}$ at $\$ 17.5 / \mathrm{t}$ ). Competition authorities would appear to have no basis to intervene upon the exercise of generator market power given benchmark returns. And any limitation on electricity tariff increases will simply send electricity retailers into bankruptcy in a similar fashion to that witnessed in California in 2000. Ultimately, the pricing of this essential commodity to market requires particularly careful policy attention.

Is the Wounded-Bull Scenario a matter that only Victoria need worry about? Certainly not. Given the availability of coal seam gas resources in southern Queensland, marginal black coal generators in Queensland and NSW face a similar threat. Consequently, a Wounded-Bull Scenario is also, in the opinion of the authors, possible in NSW and QLD in the absence of permit allocation. Finding the right permit allocation policy will be a demanding task. Nevertheless, in order to prevent a Wounded-Bull Scenario, a carefully crafted allocation policy designed to transition generating firms (as opposed to the plant) will be required to ensure that electricity prices remain stable. A complex and indeed vexed policy arena awaits the policy makers, industry and the Federal Government. 


\section{References}

AGO: Australian Greenhouse Office, 1999, National emissions trading: establishing the boundaries, Discussion paper No.1, Commonwealth of Australia, Canberra.

Argy, F. 1999, "Distribution effects of structural change: some policy implications", in Structural adjustment - exploring the policy issues, Productivity Commission, Canberra: AusInfo, pp 39-92.

Borenstein, S. and Bushnell, J. 1999, “An empirical analysis of the potential for market power in California’s electricity industry”, Journal of Industrial Economics, 47(1): 285-321.

Coase, R. 1960, “The problem of social cost”, Journal of Law and Economics, (3): 1-44.

Ergas, H. 2008, “Auctions vs grandfathering”, A Concept Economics Briefing Paper, Concept Economics, Canberra.

esaa: Energy Supply Association of Australia, 2000, 2003, 2004, “Electricity Australia”, ESAA Publication, Sydney.

French, J. 2003, “Australian Gas Light Company v Australian Competition and Consumer Commission (No 3)”, FCA 1525.

IEA: International Energy Agency, 2002, “CO2 emissions from fuel combustion”, International Energy Agency Publication, Paris.

King, S. 1998, “The Behaviour of firms in declining industries”, The Economic Record, 74(226): 217-230.

Linares, P., Santos, F., Ventosa, M. and Lapiedra, L. 2006, "Impacts of the European emissions trading scheme directive and permit assignment methods on the Spanish electricity sector, The Energy Journal, 27(1): 79-98.

McKinsey and Company, 2005, "Review of EU Emissions Trading Scheme”, McKinsey and Company Publication for the European Commission Directorate General for Environment.

NEMMCO: National Electricity Market Management Company, 2007, 'Statement of Opportunities for the National Electricity Market’, Melbourne.

NETT: National Emissions Trading Taskforce, 2006, "Possible design for a national greenhouse gas emissions trading scheme”, available at www.cabinet.new.gov.au/greenhouse

Radov, D. and Klevnas, P. 2007, “CO2 Cost Pass-Through: German Competition Regulators' Shaky Economics”, Energy Regulation Insights, NERA Economic Consulting, 31: 1-7.

Sijm, J., Bakker, S., Chen, Y., Harmsen, H. and Lise, W. 2005, "CO2 price dynamics: the implications of EU emissions trading for the price of electricity", Energy Research Centre of the Netherlands, ECN-C—05-081, Project 7.7651.

Simshauser, P. 1998, Electricity markets, price efficiency and market power, M.Com. Thesis, Griffith University, Brisbane. Available from paul.simshauser@babcockbrown.com 
Simshauser, P. 2001, “Excess entry in the deregulated Queensland power market”, Economic Policy and Analysis, 31(1): 73-92.

Simshauser, P. 2005, "The gains from the microeconomic reform of the power generation industry in East-Coast Australia”, Economic Analysis and Policy, 35(1-2): 23-43.

Simshauser, P. 2008, "The dynamic efficiency gains from introducing capacity payments in the national electricity market”, Australian Economic Review, 41(3): 349-370.

Simshauser, P., Doan, T. and Lacey, B. 2007, "The outlook for the economic and environmental performance of Australia's National Electricity Market”, Electricity Journal, 20(6):58-75.

\section{Appendix I - Data used in the NEMESYS Model}

Tables A1 to A3 present the important cost, technical, supply and demand-side data that has been input into the NEMESYS Model to produce the simulation results as illustrated in Sections 5 and 6. Specifically, Table A1 provides the cost and technical parameters of new entrant plant, Table A2 sets out the cost and technical parameters of the existing plant stock, while Table A3 provides a high level summary of the half-hourly load curve used in the simulations.

Table A1 - Assumed New Entrant Cost Parameters in Victoria

\begin{tabular}{|c|c|c|c|c|c|c|c|c|}
\hline $\begin{array}{l}\text { Generation } \\
\text { Technology }\end{array}$ & $\begin{array}{r}\text { Capital } \\
\text { Cost } \\
(\$ / \mathrm{kW}) \\
\end{array}$ & (MW) & $\begin{array}{r}\text { Variable } \\
\text { O\&M } \\
(\$ / \mathrm{MWh}) \\
\end{array}$ & $\begin{array}{r}\text { Fixed } \\
\text { O\&M } \\
(\$ \mathrm{M} \text { pa }) \\
\end{array}$ & Useful Life & $\begin{array}{l}\text { Heat Rate } \\
(\mathrm{kJ} / \mathrm{kWh})\end{array}$ & Fuel Cost & Auxillaries \\
\hline Brown Coal & 2,100 & 500 & 1.00 & 16.0 & 50 & 12,908 & 0.35 & 0.07 \\
\hline NGCC & 1,250 & 350 & 2.50 & 5.0 & 30 & 7,200 & 3.20 & 0.01 \\
\hline OCGT & 750 & 150 & 8.00 & 2.0 & 30 & 11,500 & 4.50 & 0.00 \\
\hline Cost of Capital (\%) & 11.00 & & & & & & & \\
\hline
\end{tabular}

Table A2 - Victoria Supply-Side Data

\begin{tabular}{|c|c|c|c|c|c|c|c|c|c|c|c|c|c|}
\hline Plant stock & $\begin{array}{r}\text { Units } \\
(\#)\end{array}$ & $\begin{array}{r}\text { Size } \\
(\mathrm{MW})\end{array}$ & $\begin{array}{r}\text { Capacity } \\
\text { (MW) }\end{array}$ & $\begin{array}{r}\text { Availability } \\
(\%)\end{array}$ & $\begin{array}{r}\text { Min Load } \\
(\%)\end{array}$ & $\begin{array}{r}\text { Efficiency } \\
(\%)\end{array}$ & $\begin{array}{l}\text { Heat Rate } \\
(\mathrm{kJ} / \mathrm{kWh})\end{array}$ & $\begin{array}{r}\text { Unit Fuel } \\
(\$ / G J)\end{array}$ & $\begin{array}{l}\text { Fuel Cost } \\
\text { (\$/MWh) }\end{array}$ & $\begin{array}{r}\text { Var O\&M } \\
\text { (\$/MWh) }\end{array}$ & $\begin{array}{r}\text { SRMC } \\
(\$ / M W h)\end{array}$ & $\begin{array}{r}\text { Emissions } \\
\text { (t CO2/MWh) }\end{array}$ & $\begin{array}{r}\text { SRMC at } \$ 17.50 / \mathrm{t} \\
(\$ / \mathrm{MWh})\end{array}$ \\
\hline Renewables & 10 & various & 245 & 37 & 100 & - & - & - & - & - & - & - & - \\
\hline Brown 1000MW & 2 & 500 & 1000 & 91 & 50 & 28.05 & 12,834 & 0.35 & 4.49 & 1.00 & 5.49 & - & 5.49 \\
\hline Brown 2000MW & 2 & 500 & 2000 & 91 & 50 & 27.89 & 12,908 & 0.35 & 4.52 & 1.00 & 5.52 & 1.26 & 27.57 \\
\hline Brown 1450MW & 4 & $350 / 375$ & 1450 & 91 & 50 & 25.90 & 13,900 & 0.35 & 4.86 & 1.00 & 5.86 & 1.37 & 29.84 \\
\hline Brown 1600MW & 8 & 200 & 1600 & 91 & 50 & 23.92 & 15,050 & 0.35 & 5.27 & 1.00 & 6.27 & 1.46 & 31.82 \\
\hline Brown 160MW & 1 & 160 & 160 & 90 & 50 & 23.76 & 15,152 & 0.35 & 5.30 & 1.00 & 6.30 & 1.4 & 30.80 \\
\hline Brown 195MW & 3 & 65 & 195 & 90 & 50 & 23.76 & 15,152 & 0.35 & 5.30 & 1.00 & 6.30 & 1.5 & 32.55 \\
\hline NSW Interconnect & $\mathrm{n} / \mathrm{a}$ & 1900 & 1900 & 99 & 0 & 35.60 & 10,112 & 1.4 & 14.16 & 1.00 & 15.16 & 0.9 & 30.91 \\
\hline New CCGT & 1 & 350 & 350 & 92 & 30 & 50.50 & 7,129 & 3.2 & 22.81 & 2.20 & 25.01 & 0.36 & 31.31 \\
\hline Gas-Steam 500MW & 1 & 500 & 500 & 94 & 0 & 35.00 & 10,286 & 3.2 & 32.91 & 2.00 & 34.91 & 0.52 & 44.01 \\
\hline Hydro 500MW & 15 & various & 500 & 94 & 0 & - & - & - & - & - & - & - & - \\
\hline OCGT 92MW & 2 & 46 & 92 & 90 & 0 & 36.00 & 10,000 & 3.2 & 32.00 & 8.00 & 40.00 & 0.51 & 48.93 \\
\hline OCGT 300MW & 2 & 150 & 300 & 94 & 0 & 31.00 & 11,613 & 3.2 & 37.16 & 8.00 & 45.16 & 0.59 & 55.49 \\
\hline OCGT 150MW & 4 & 37.5 & 150 & 90 & 0 & 26.00 & 13,846 & 3.2 & 44.31 & 8.00 & 52.31 & 0.7 & 64.56 \\
\hline OCGT 300MW & 6 & 50 & 300 & 90 & 0 & 26.00 & 13,846 & 4.5 & 62.31 & 8.00 & 70.31 & 0.7 & 82.56 \\
\hline OCGT 455MW & 7 & $51 / 76$ & 455 & 90 & 0 & 26.00 & 13,846 & 4.5 & 62.31 & 8.00 & 70.31 & 0.7 & 82.56 \\
\hline
\end{tabular}

Table A3 - Victoria Demand-Side Data (Load Data)

\begin{tabular}{lrl}
\hline Summary of Half-Hourly Load Data (17,520 points) \\
\hline Energy Demand & 51,261 & GWh \\
Maximum Load & 8,886 & MW \\
Minimum Load & 3,966 & MW \\
Average Load & 5,852 & MW \\
Median Load & 5,820 & MW \\
Load Factor & 65.85 & $\%$ \\
\hline
\end{tabular}




\footnotetext{
${ }^{1}$ We define the intermediate run as being the period up to the point of new entry, that is, up to five years.

${ }^{2}$ AGO (1999) and NETT (2006) provide useful discussions on the advantages of emissions trading by comparison to, for example, carbon taxes or emission standards.

${ }^{3}$ Multi-period discounted cash flow modelling revealed that if the remaining useful life was certain to be 10 years, the required return would be approximately 18 per cent per annum. However, a remaining useful life of, say 71/2 years, requires an annual return of circa 23 per cent. Thus, the target return is highly sensitive to remaining economic life. ${ }_{5}^{4}$ If the price of $\mathrm{CO}_{2}$ was substantially lower, then there would be little need for such analysis in the first place.

$\left.5 \quad \mathrm{P}_{\mathrm{CO} 2}=\underline{\left[\mathrm{GJ} / \mathrm{MWh}_{\mathrm{NGCC}}\right.} \underline{\mathrm{xp}}_{\mathrm{g}}+\mathrm{VOM}_{\mathrm{NGCC}}\right]-\left[\mathrm{GJ} / \mathrm{MWh}_{\mathrm{MBC}} \underline{\mathrm{xp}}_{\underline{\mathrm{c}}}+\mathrm{VOM}_{\mathrm{MBC}}\right]$

$\left[\mathrm{t}_{\mathrm{CO} 2} / \mathrm{MWh}_{\mathrm{MBC}}-\mathrm{t}_{\mathrm{CO} 2} / \mathrm{MWh}_{\mathrm{NGCC}}\right.$

Where: $\quad \mathrm{p}_{\mathrm{CO} 2}=$ benchmark price of $\mathrm{CO}_{2}$ for fuel switching $(\$ / \mathrm{t})$

$\mathrm{GJ} / \mathrm{MWh}_{\mathrm{NGCC}} \quad=$ heat rate of an efficient single shaft NGCC

$\mathrm{p}_{\mathrm{g}} \quad=$ delivered price of natural gas $(\$ / G J)$

$\mathrm{VOM}_{\mathrm{NGCC}} \quad=$ variable $\mathrm{O}$ and $\mathrm{M}$ costs of a NGCC plant $(\$ / \mathrm{MWh})$

$\mathrm{GJ} / \mathrm{MWh} \mathrm{hBC}_{\mathrm{MBC}} \quad=$ heat rate of the marginal brown coal generator

$\mathrm{P}_{\mathrm{C}} \quad$ = delivered price of coal $(\$ / \mathrm{GJ})$

$\mathrm{VOM}_{\mathrm{MBC}}=$ variable $\mathrm{O}$ and $\mathrm{M}$ costs of marginal brown coal plant $(\$ / \mathrm{MWh})$

$\mathrm{t}_{\mathrm{CO} 2} / \mathrm{MWh}_{\mathrm{MBC}} \quad=$ emissions intensity of the marginal brown coal plant

$\mathrm{t}_{\mathrm{CO} 2} / \mathrm{MWh}_{\mathrm{NGCC}}=$ emissions intensity of an NGCC plant

In the case of Victoria, this can be quantified as follows:

$$
\mathrm{P}_{\mathrm{CO} 2}=[7.20 \times \$ 3.20 / \mathrm{GJ}+\$ 2.50 / \mathrm{MWh}]-[15.05 \times \$ 0.35 / \mathrm{GJ}+\$ 1.00 / \mathrm{MWh}]
$$$$
\mathrm{p}_{\mathrm{CO} 2}=\$ 17.50 / \mathrm{t} \text { (approx). }
$$

${ }^{6}$ This assumes NSW black coal plant to have a heat rate of $10.1 \mathrm{GJ} / \mathrm{MWh}$, a unit fuel cost of $\$ 1.40 / \mathrm{GJ}$ and a $\mathrm{CO}_{2}$ intensity of $0.9 \mathrm{t} \mathrm{CO}_{2} / \mathrm{MWh}$.

${ }^{7}$ NEMMCO has a number of excellent publications on the operation of the market such as Wholesale Market Operation and Trading arrangement in the NEM, accessed via its web site at www.nemmco.com.au

${ }^{8} 2006$ was selected due to the stable operating conditions that prevailed during that period.

${ }^{9}$ The implication is that transfers along the South Australian and Tasmanian interconnects are minimal. South Australia is a small and finely balanced 3,400MW system whereas the 2,000MW Tasmanian system is an energylimited hydro system. Thus, while both of these neighbours provide useful 'capacity sharing' to ensure reliable supplies, they are incapable of providing substantial energy (as opposed to capacity) quantities to the 10,000MW Victorian grid. New South Wales on the other hand comprises a large 15,000MW system. Transfers between Victoria and New South Wales are very significant, and as subsequent analysis will show, the direction of those flows can reverse when $\mathrm{CO}_{2}$ is priced. Accordingly, the Interconnect between Victoria and New South Wales must be incorporated in any dynamic partial equilibrium modelling.

${ }^{10}$ The assumption here is a capital value of $\$ 2.2$ billion, 70 per cent debt financed at an average interest rate of 8 per cent.

${ }^{11}$ The fact that a generator faces financial distress is enormously significant. Driving prices above new-entrant levels is a short-run profit maximising strategy. If pursued over the long run, as occurred in Queensland between 1998 and 2002, the most likely outcome will be an 'excess entry result' (see Simshauser, 2001). This in turn ultimately leads to a price collapse and suboptimal economic returns.

${ }^{12}$ We assume a demand elasticity of -0.19 which is consistent with those results in Borenstein and Bushnell (1999). Note that we opted to apply this to aggregate demand, even though the authors suspect that large industrial loads from the aluminium, metals (iron and steel) and mining sectors which comprise more than 20 per cent of load will be carvedout of an emissions trading scheme, thus being shielded from $\mathrm{CO}_{2}$ pricing.

${ }^{13}$ Predictably, under this extreme scenario, the gas and hydro machines, with their low and zero emission footprints, earn economic returns that are too high to plot on our y-axis.
} 